\title{
Análise teórica para desvendar o lento aceite da recente verticalização residencial em San José, Costa Rica
}

\author{
Theorical analysis to explain the slow acceptance of the recent residential \\ vertical trends in San José, Costa Rica
}

Sabrine Acosta[a,b]

\author{
[a] Universidad de Costa Rica (UCR), Escuela de Geografía, San José, Costa Rica \\ [b] Université Sorbonne Nouvelle - Paris 3, Institut des Hautes Etudes de l'Amérique Latine, Centre de Recherche et de \\ Documentation des Amériques, Unité de Recherche 7227, Paris, France
}

\section{Resumo}

0 artigo tem como objetivo avaliar o surgimento e evolução do mercado imobiliário costarriquenho com o intuito de desvendar o contexto do forte vínculo com a terra e, por conseguinte, propor uma explicação ao lento aceite das novas tendências residenciais verticais. A metodologia consiste em pesquisas de campo anuais entre 2011 e 2017, revisão de fotografias e uma revisão bibliográfica de autores marxistas costarriquenhos, brasileiros e internacionais, com a intenção de formular uma discussão teórica para mostrar como as mudanças nos modos de produção e na economia local fortaleceram a relação entre a população e sua terra. Utiliza-se um amplo recorte temporal desde o período colonial até a atualidade com o intuito de analisar como, ao longo da evolução do mercado imobiliário, as diferentes formas de moradia permitiram manter esse forte arraigo pela terra. Posteriormente aborda-se o tema da recente verticalização residencial de luxo e se realiza uma análise semântica dessa, com a intenção de entender a reação da população frente a uma proposta residencial sem acesso a jardim ou espaço ao ar livre. Conclui-se que, embora possam existir outros fatores, o forte arraigo pela terra pode ser considerado um dos motivos principais do lento aceite dos novos empreendimentos verticais na Costa Rica.

Palavras-chave: Mercado imobiliário. Moradia vertical. Assentamentos coloniais. Crescimento urbano.

\section{Abstract}

This article aims to evaluate the emergence and evolution of the Costa Rican real estate market in order to unravel the context of the strong bond with the land and hence the slow acceptance of new residential vertical trends. The methodology consists of annual fieldworks between 2011 and 2017, a revision of some local antique urban photographs and a bibliographical review of Costa Rican, Brazilian and international Marxist authors, with the purpose of formulating a theoretical discussion to show how changes in the modes of production and the local economy strengthened the relationship between people and their land. A broad time frame is analyzed, from the colonial period until nowadays, in order to examine, how across the course of the evolution of the real estate market, the different forms of housing have adapted to preserve the strong attachment that the population has had for their land. Afterward, the issue of the recent emergence of luxury vertical buildings is

SA é mestra em Geografía, e-mail: sabrigeografia@hotmail.com 
addressed and a semantic analysis is done to examine the population's response to the new residential proposal without access to open space. It is concluded the strong attachment to the land may be one of the main reasons for the slow acceptance of new vertical developments in Costa Rica, even though there might exist other factors.

Keywords: Real estate market. Vertical housing. Colonial towns. Urban growth.

\section{Introdução}

O presente artigo realiza um amplo recorte temporal desde o período colonial até a atualidade para apresentar o contexto dos inícios do mercado imobiliário e entender a evolução do forte arraigo do costarriquenho pela sua terra como fator principal do lento aceite da verticalização residencial em San José, Costa Rica. 0 amplo recorte temporal se justifica para poder enfatizar a especificidade do local e ajudar a entender a situação atual das novas tendências residenciais.

Entre diversos possíveis fatores que expliquem a lenta produção imobiliária vertical, esta pesquisa se foca no forte arraigo pela terra desde a época colonial. A análise se realizará desde o ponto de vista econômico, político e social, através de uma revisão bibliográfica de autores costarriquenhos, brasileiros e outros internacionais e marxistas. Esta abordagem, pautada nos fundamentos do materialismo histórico, se apresenta como uma inovação para a análise desde a perspectiva da geografia urbana costarriquenha, já que este marco referencial teórico tem sido pouco abordado na geografia local. Este é o motivo pelo qual a presente pesquisa se foca principalmente na revisão e discussão bibliográfica complementada pela revisão de fotografias antigas e pesquisa de campo entre 2011 e 2017.

Através dessa revisão histórico-geográfica observar-se-á como as mudanças nos modos de produção contribuíram para manter o forte arraigo pela terra em vez de provocar um deslocamento do proletariado. Assim mesmo, a partir da inserção da Costa Rica no mercado mundial com a exportação cafeeira, no século XIX, se apresentarão as modificações na organização social e espacial dos povoados e os padrões de posse da terra para entender como as mudanças no modo de produção repercutiram na distribuição das propriedades e na produção do espaço urbano (Schnell, 2013). Analisar-se-ão diversos autores para mostrar as tendências da posse da terra e as incipientes transações imobiliárias, a fim de desvendar padrões durante o crescimento urbano e ressaltar como o arraigo pela terra tem se mantido forte ao longo dos séculos, até enfrentar uma nova proposta de moradia verticalizada. A Figura 1 apresenta a localização geográfica atual da Costa Rica e sua capital San José.

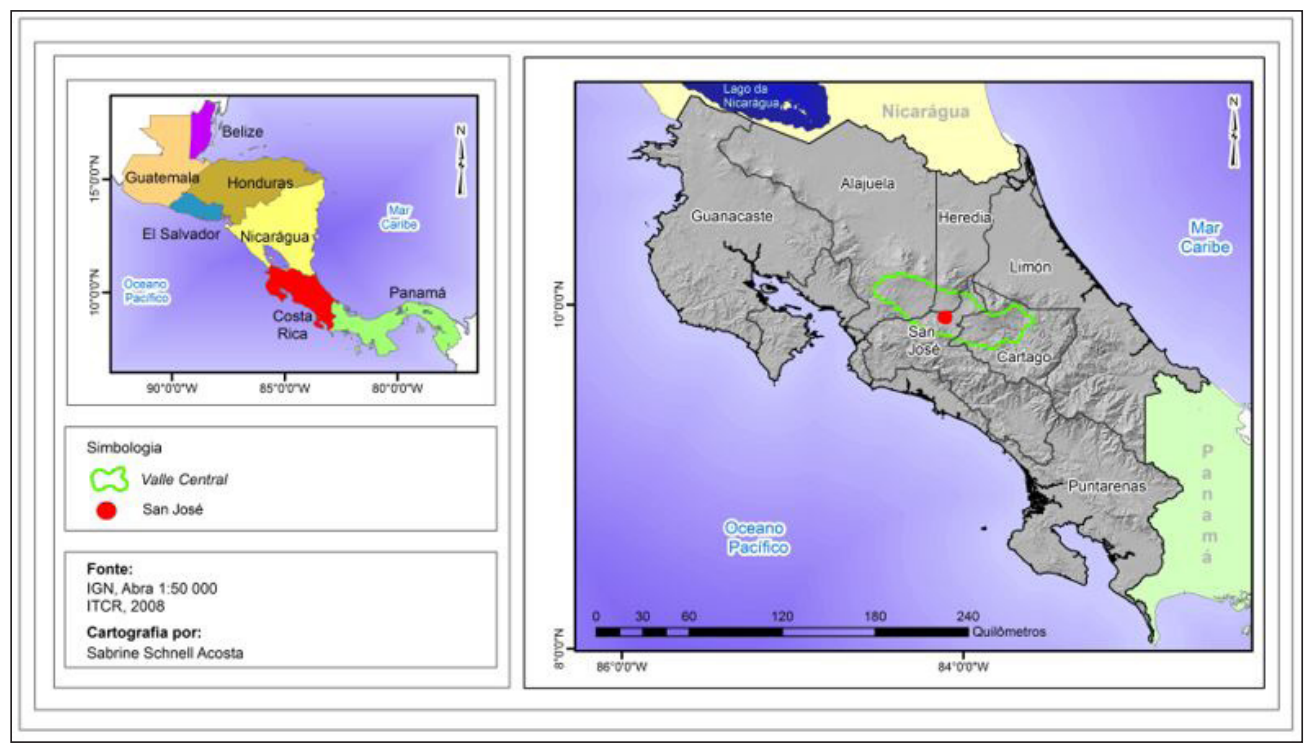

Figura 1 - Localizaç̃̃o geográfica da Costa Rica Fonte: Schnell (2014), IGN (1989) e ITCR (2008). 


\section{Discussão teórico-conceitual: desde o processo de formação do mercado imobiliário à atualidade}

Para entender a atual dinâmica e aceite dos espaços residenciais na capital, San José, é preciso analisar os fenômenos espaciais e sua essência como parte da estrutura de uma totalidade (Marx, 1983; Saad, 2011; Lukács, 1981). Segundo Santos (2012, p. 31), "[...] o conceito de totalidade é uma construção válida no exame da complexidade de fatores a serem examinados na análise do contexto espacial". Consideram-se os últimos seis séculos para se analisar a essência dos fenômenos que estão interagindo para compor a totalidade estudada (Marx, 1983), já que a totalidade está em movimento e não é estática. Observar-se-ão as mudanças nos padrões da posse da terra ao longo do tempo para entender o forte arraigo atual pelo espaço aberto, chácaras e jardins.

Em vez de optar por uma metodologia de realizar entrevistas abordando opiniões sobre a situação atual, decidiu-se realizar uma busca histórico-geográfica, complementada por uma pesquisa de campo e análise de fotografias, para desvendar os motivos ancestrais de uma relação arraigada e sentimental do costarriquenho com a terra já que "[...] a história está sempre se refazendo" (Santos, 2012, p. 103). 0 que hoje aparece como resultado é também um processo; um resultado hoje é também um processo que amanhã vai se tornar outra situação. 0 processo é o permanente devir (Santos, 2012). Dessa maneira, se concorda com Sposito (2002, p. 11), que

[...] o espaço é história, e nesta perspectiva, a cidade de hoje é o resultado cumulativo de outras cidades de antes, transformadas, destruídas, reconstruídas, enfim produzidas pelas transformações sociais ocorridas através dos tempos.

Assim se justifica o amplo recorte histórico na discussão bibliográfica como metodologia para analisar os motivos da resistência histórica dos costarriquenhos no aceite dos novos projetos imobiliários verticais. Esta metodologia foi apoiada por pesquisa de campo na qual os registros fotográficos atuais confirmam os resultados da discussão, evidenciando poucas construções em altura e apenas um recente processo de verticalização.
Estudando as origens do mercado imobiliário em San José, se contextualizou o processo de verticalização como uma característica recente do processo de metropolização. A variável tempo é indispensável na relação entre forma, função e estrutura, pois é ele que indica o movimento do passado ao presente. "Cada forma sobre a paisagem é criada como resposta a certas necessidades ou funções do presente" (Santos, 2012, p. 73). Nesse caso, observar-se-á como as inovações tecnológicas antissísmicas não foram suficientes para vencer o aceite ao novo padrão edilício e como prevaleceu o arraigo, explicado através da análise teórica.

Segundo Milton Santos (2012, p. 37), "[...] o espaço é o resultado da geografização de um conjunto de variáveis, de sua interação localizada e não dos efeitos de uma variável isolada [...]". Dessa forma, ressalta-se a importância de se retomar a discussão desde o período colonial, utilizando diversas perspectivas e aportes teóricos. Posteriormente o autor afirma que

[...] uma variável sozinha não define uma situação de mudança. Considerá-la como se estivesse mudando sozinha é falso. As mudanças atingem contextos, pois não há mudança que não seja contextual: as coisas, o fato, o homem, apenas existem e valem dentro de uma relação [...] (Santos, 2012, p. 110).

Dessa maneira se explica que esta pesquisa procurará contextualizar o processo de verticalização no quadro do desenvolvimento do mercado imobiliário para entender seu lento aceite em pleno século XXI.

A seguir se dará início à revisão das cidades coloniais e das relações econômicas, políticas e sentimentais da população com elas, com o intuito de revelar os primeiros arraigos com a terra.

\section{O contato com os europeus: uma nova organização social e espacial}

Durante o período colonial, a localização das novas cidades no atual território costarriquenho era planejada com respeito à disponibilidade de recursos e também seguindo as necessidades e objetivos político-religiosos. Origina-se a formação do sistema urbano com base na exploração colonial (Schnell, 2013, 2014). As terras se repartiram e a formação das incipientes cidades obedecia às Leyes de las Indias, 
que era o documento que regulava as normas para a fundação e organização dos povoados.

Esse documento colonial estabelecia como devia ser o traçado dos quadrantes, a localização da praça maior, a igreja e a repartição dos solares. Assim, desde o momento em que os espanhóis repartiram as terras entre os locais, a população sempre manteve o contato com pastos, hortas e terrenos comunais. Essas foram das primeiras formas de ordenar o território em função das necessidades políticas, econômicas e religiosas, sempre mantendo um forte contato com a terra (Schnell, 2013, 2014).

Quanto ao surgimento de San José, esse foi um processo lento e complicado, no entanto é revelador para ilustrar o forte arraigo pela terra (Schnell, 2014). Essa cidade surgiu com um pequeno grupo de casas e uma população que foi obrigada e ameaçada para ficar.

De acordo com Schnell (2014), para entender esse processo é importante destacar que os motivos religiosos fomentaram a formação de vários povoados durante o século XVIII. Ordenou-se a construção de ermidas e oratórios, que agiram como elementos religiosos estruturadores dos novos espaços. Os governantes ameaçavam e puniam as famílias para obrigá-las a povoar os diferentes lugares. Em San José, a primeira ermida foi construída em 1737 (Núñez, 1973) e diversos pesquisadores ${ }^{1}$ consideram essa data como o início de San José. Foi um processo lento no qual, em 1751, de acordo com González (1973, p. 113)², "San José era apenas um número insignificante de casas e ranchos dispersos com uma ermida". Um dos motivos que dificultava a moradia era a falta de água no lugar. Foi em 1751 que o Padre Pomar ${ }^{3}$ se comprometeu a facilitar a água para a cidade. Mas, uma vez esse problema resolvido, a população continuou recusando-se a morar longe de suas fazendas. 0 arraigo pela própria terra era forte e foi um processo forçado, no qual a população demonstrou seu vínculo. Segundo González (1973, p. 115) ${ }^{4}$, o motivo "[...] era algo mais fundamental e insuperável. Era o amor pelo pedaço de

\footnotetext{
${ }^{1}$ Ver González (1973); Núñez (1973); Quesada (2011); Vega (1981a, 1981b); Bustamante (1996); Molina (1991); entre outros, para detalhes sobre o processo de surgimento da cidade San José.

2 Tradução nossa.

${ }^{3}$ Sacerdote Juan de Pomar Burgos, principal impulsor da villa e do abastecimento de água.

${ }^{4}$ Tradução nossa.
}

terra, pela pequena chácara que se cultivava junto com a mulher e com os filhos e [em] que [se] procurava o alimento para todos". Eis a importância de entender a relação entre o costarriquenho e a terra ou o espaço para cultivar seus produtos, fator que atualmente age como um obstáculo para os costarriquenhos na hora de mudar de um tipo de moradia horizontal, espaçosa, para um sistema vertical que implica na ausência dos espaços abertos, jardins e terras de cultivo (Schnell, 2013; Acosta, 2017).

0 fator econômico que influenciou de maneira importante o incipiente desenvolvimento de San José, permitindo manter o arraigo pela terra, foi a produção de tabaco. Esse produto iniciou um processo de mudanças nas cidades e nas economias locais. A terra sempre foi fonte de trabalho e produtos de consumo ou troca. 0 desenvolvimento mais estável da cidade de San José deu-se somente a partir de 1760. A cidade começou a expandir-se e sua nova dinâmica comprova que "[...] a construção da paisagem converte-se em um legado aos tempos futuros" (Santos, 2012, p. 73).

\section{A inserção da Costa Rica no mundo capitalista e as incipientes cidades no Valle Central}

A seguir, se realizará uma análise, do ponto de vista econômico, desde a inserção do território no mundo capitalista, com o intuito de entender esse forte arraigo pela terra. Molina (1991, p. 271) explica que o capitalismo se forjou a partir de uma "[...] mutação paulatina entre o comerciante e o camponês"5. Por conseguinte, concordamos com Vega (1981a) que no caso da Costa Rica a gênese do capitalismo no território resultou numa simbiose entre o modo de produção capitalista e o de subsistência, permitindo manter o contato com a terra (Schnell, 2013; Acosta, 2017). Segundo Molina (1991, p. 162),

A chave está no equilíbrio de forças sociais entre o comerciante e camponês: a raiz da pobreza provincial, o sector empresarial era estruturalmente fraco e não tinha o poder necessário para subjugar de formabrutal ao produtor direto; dado o tipo de extração do excedente, a existência da unidade doméstica não estava em perigo. 0 agricultor do Planalto

${ }^{5}$ Tradução nossa. 
Central ${ }^{6}$ que consolidava dia após dia liberdade e acesso à terra, conseguiu e soube ser livre, ao contrário do mitayo ${ }^{7}$ do Peru e do indígena da Guatemala ${ }^{8}$.

Esses dados contribuem para explicar que a situação econômica da população, as mudanças nos modos de produção e nas relações sociais permitiram aos locais manter a relação com suas chácaras de produção de subsistência. Molina (1991) expõe que um alto crescimento demográfico levou a uma maior divisão, por herança, das terras, o que implicou numa falta de acesso à terra. Como consequência, fomentou-se que camponeses procurassem trabalho em fazendas cafeeiras alheias, mantendo assim o trabalho assalariado e conservando suas pequenas propriedades familiares para a produção de bens de consumo próprio. Dessa forma não se caiu numa proletarização massiva, como ocorreu em outros países da América Central e Latina em geral. Isso comprova que a formação social da época teve consequências na distribuição e hierarquização da propriedade fundiária, base e cenário dos processos de urbanização do século XX (Schnell, 2014).

As relações entre a produção camponesa e as de extração se mantiveram estáveis, permitindo a existência da propriedade camponesa para subsistência e, ao mesmo tempo, uma relação de trabalho assalariado em terras alheias como fonte de ingresso alternativo. Isto corrobora o assinalado por Molina (1991, p. 248)'

0 assalariado cafeeiro não era um proletário. A força de trabalho, adquirida pelo empregador, geralmente vinha do fazendeiro pobre, dono de uma pequena terra, que lutava para complementar a renda proveniente do cultivo da sua própria fazenda, enquanto se aguardava a maturidade e a herança.

Entre 1744 e 1819 se legalizou a ocupação do solo no território que corresponde atualmente à Costa Rica (Molina, 1991). A coexistência dos dois tipos de produção é de suma importância, já que essa especificidade do lugar determinou e orientou

\footnotetext{
${ }^{6}$ Outra forma local de referir-se ao Valle Central.

7 Índio que fazia parte do sistema de trabalho forçado aplicado pela Coroa espanhola em tempos coloniais na região andina.

8 Tradução nossa.

${ }^{9}$ Tradução nossa.
}

o desenvolvimento e produção do espaço urbano e as recentes tendências do mercado imobiliário. Esse é o motivo pelo qual atualmente, em uma época de intensificação da verticalização residencial, o costarriquenho apresenta forte arraigo pela terra e pela sua propriedade privada.

O contexto exposto foi o início de uma divisão social que teve diferentes graus de participação nos processos econômicos e políticos no decorrer dos séculos e, por conseguinte, diferentes formas de acesso à terra e participação na rede comercial. Dessa maneira, se concorda com Lefebvre (1995, p. 404), que afirma que: "0 mercado mundial cria configurações e se inscreve mudando espaços na superfície da terra, espaços regidos por conflitos e contradições".

Essa análise de amplo recorte histórico possibilita observar como a propriedade privada começou a surgir no Valle Central e sempre conservou o padrão da agricultura de subsistência, permitindo manter o forte arraigo pela terra. Dessa forma, a agricultura comercial proporcionava o que o sistema capitalista requeria: "[...] uma posição servil da massa do povo, sua transformação em trabalhadores de aluguel e a de seus meios de trabalho em capital" (Marx, 1988, p. 266). Nesse contexto, cresceu no Valle Central a condição de trabalhadores assalariados e que não foram despojados de suas terras, já que não aconteceu uma acumulação primitiva, como aponta Vega $\left(1988\right.$, p. 163) ${ }^{10}$ :

[...] não ocorreu no país, e muito menos na região cafeeira, uma acumulação primitiva que tenha despojado os antigos agricultores de suas terras, proletarizándo-os; ou como em outras partes da América Central ao difundirse o café, submetendo-os a métodos despóticos, extraeconômicos ou pré-capitalistas de extração dos excedentes.

\section{O horizonte a partir da introdução do café na economia da província}

Com o intuito de inserir o país no mercado mundial, surgiram novas atividades, movimentos migratórios e novas formas de posse da terra, os quais contribuíram para mudar a paisagem costarriquenha (Schnell, 2014). Aconteceu toda uma revolução na qual se

\footnotetext{
${ }^{10}$ Tradução nossa.
} 
abandonaram as práticas de cultivo predominantes na colônia, orientando a economia para o monocultivo. Modificou-se a organização social e espacial dos povoados, os vínculos com o mundo exterior e os padrões de posse da terra. Isso se comprova com a ideia de Santos (2012, p. 73), que estabelece que "[...] a paisagem é a herança de muitos momentos, já passados, o que levou Lenin a dizer que a grande cidade é uma herança do capitalismo e veio para ficar". Um exemplo da paisagem de San José nos inícios do século XX se observa na Figura 2. Confirma-se a falta de verticalização residencial e uma expansão urbana horizontal. Os prédios de mais de um andar correspondiam aos edifícios do governo, ao Teatro Nacional (observado na Figura 2) ou às igrejas, como a Catedral (também identificada detrás do teatro).

Nesse contexto de surgimento de povoados no Valle Central, o território costarriquenho foi testemunha da gênese do capitalismo, o qual foi condicionado pela estrutura socioeconômica legada pela colônia. As famílias e comunidades estavam participando de uma rede de relações mercantis, com uma economia monetária que pouco a pouco se internacionalizava, mas sempre mantendo seu vínculo com a própria propriedade ou terreno. De acordo com Schnell (2014, p. 219), “[...] a renda do solo passou a ser capitalizada e a propriedade e suas funções produtivas e extrativas foram recondicionadas em favor do capital estrategicamente localizado nas redes de financiamento e do comércio". Eis aqui a importância de reiterar por que, atualmente, os costarriquenhos se sentem identificados com a posse de seu próprio terreno - e os atuais empreendimentos residenciais verticais implicam numa mudança para padrão residencial sem acesso ao espaço aberto ou a jardins.

\section{O processo de metropolização e o surgimento de um mercado imobiliário}

No amplo recorte temporal analisado, cabe avançar até o século XIX para ressaltar quando a reprodução do espaço urbano teve um duplo significado: ampliação do espaço habitável e profundas transformações na propriedade fundiária - a terra urbana se vendia como mercadoria e teve uma grande importância no processo de acumulação. A terra passou a ser objeto de transações lucrativas por força da urbanização e da

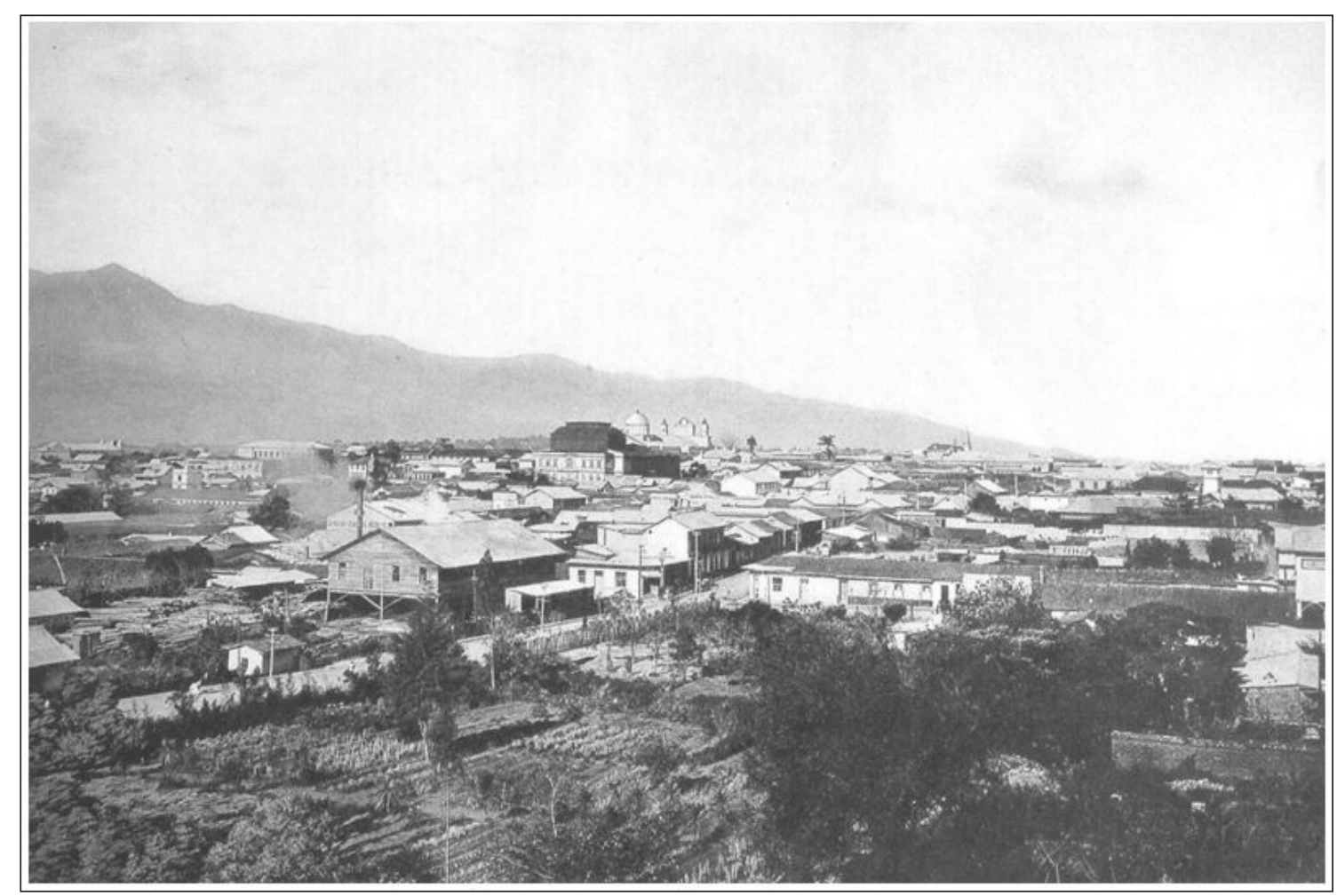

Figura 2 - Vista do centro de San José, aproximadamente nos inícios do século XX Fonte: Gómez \& Zamora (2008). 
valorização da infraestrutura urbana (Souza, 1994). Começou a diferenciar-se a terra rural da terra urbana ${ }^{11}$.

A formação da propriedade territorial foi considerada como um fenômeno do século XIX, relacionada com a expansão cafeeira e mantendo o arraigo com a terra (Schnell, 2014). Hall (1976, p. 171) ${ }^{12}$ explica a paisagem da seguinte forma:

A área das principais cidades do Planalto Central, logicamente, tem aumentado gradualmente desde a sua fundação em tempos coloniais. Durante o século XIX, a empresa francesa Tournón, por exemplo, transformou plantações de café circundantes a San José, no elegante subúrbio residencial chamado Barrio Amón; durante os anos 1930 e 1940, San Pedro de Montes de Oca tornou-se, em uma pequena vila de cafeeiros, em um subúrbio residencial de San José. Mas a expansão territorial das grandes cidades foi muito acelerada após a Segunda Guerra Mundial, e especialmente após a queda dos preços do café em 1958. A quantidade de antigos terrenos agrícolas, geralmente plantações de café, que têm sido incorporada a áreas urbanizadas, é provavelmente ainda maior, em proporção, que a forma em como o crescimento da população urbana tem se desenvolvido.

Essas terras que previamente eram parte de cafezais no século XIX, atualmente estão ocupadas por espaçosas casas de alto padrão. São propriedades com jardins e amplos espaços verdes, normalmente ocupadas por embaixadas ou atualmente demolidas para dar espaço a novos espaços verticais (Figura 3).

Continuando com as tendências no século XIX, cabe destacar que se formou um mercado imobiliário como uma atividade independente e especializada.

\footnotetext{
${ }^{11}$ Essa última se relaciona com o processo produtivo da edificação e isso se chama articulação primária da terra urbana, segundo Jaramillo (2009). A diferença em relação à terra rural é que a urbana se relaciona, durante toda a vida útil, com o seu produto: o imóvel. As possibilidades de utilização desse produto dependem da forma particular de inserção do terreno na dinâmica espacial de todos os outros valores de uso na cidade (Jaramillo, 2009). As relações da terra urbana com os processos econômicos através do espaço construído no momento de seu consumo são denominadas articulação secundária. Essa é a principal diferença em relação à terra rural.

12 Tradução nossa.
}

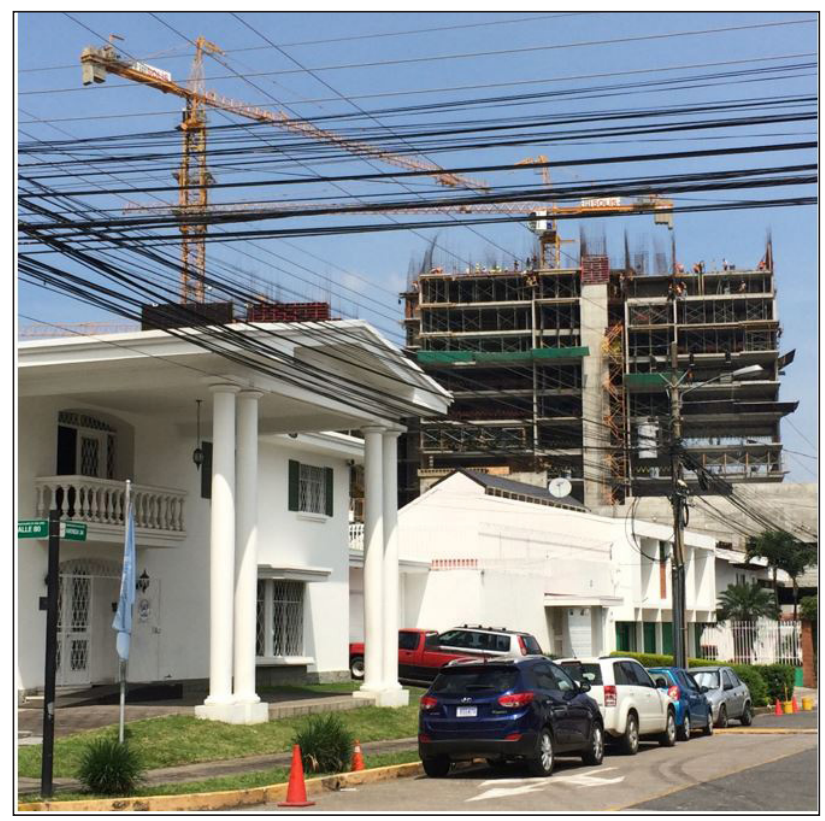

Figura 3 - Novos projetos verticais ocupando os espaços de casas de alto padrão no bairro Rohrmoser, antigamente cafeeiro

Fonte: Acervo do autor (agosto de 2016).

O número de terras vendidas aumentou desde a independência e nas últimas décadas do século XIX, corroborando a consolidação do mercado imobiliário no território (Baires, 1975). 0 surgimento do mercado imobiliário propiciou o loteamento do solo urbano e se fomentou um padrão de crescimento urbano horizontal. Esse crescimento predominantemente horizontal se confirma na Figura 4.

A cidade "sustenta relações de produção e de propriedade" (Lefebvre, 2006, p. 46) e essa nova dinâmica da propriedade imobiliária respondeu às novas relações de produção, aos novos mercados e assim determinou a magnitude e direção da ação expansiva territorial, sempre mantendo o forte arraigo pela terra.

Embora não seja objetivo deste artigo discutir em detalhe as mudanças no valor fundiário, cabe assinalar que a tendência assistemática (sem controle estatal) para definir os usos urbanos da terra propiciou um aumento no valor fundiário e uma apropriação de benefícios mais significativos para seus proprietários que a resultante das atividades de produção agrícola tradicional (Schnell, 2014). Comparando-se essa situação com o panorama atual, pode-se relacionar esse momento histórico de forte e rápida mudança do uso do solo com o que está acontecendo com os novos 


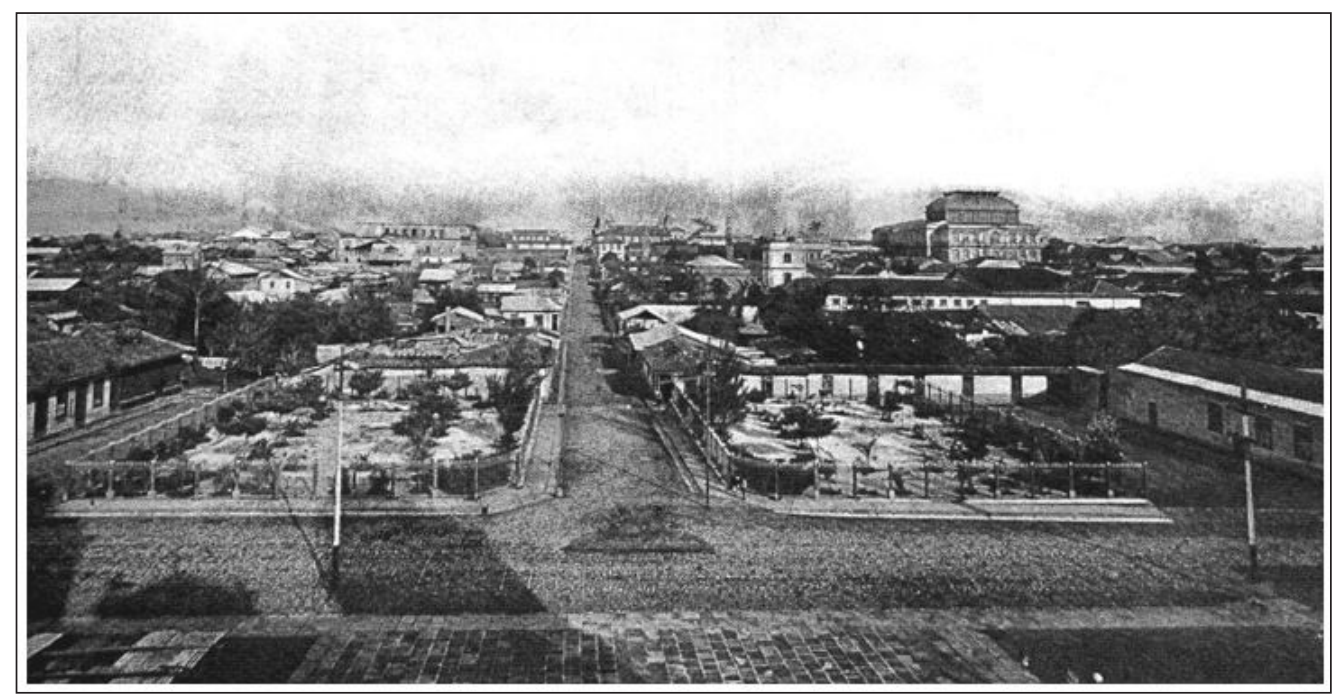

Figura 4 - Crescimento horizontal no centro de San José, nos inícios do século XX Fonte: Gómez \& Zamora (2008).

empreendimentos residenciais verticais. Atualmente, os grandes projetos verticais de uso misto também estão atuando com força, definindo novos valores fundiários e determinando novos usos do solo.

\section{O mercado imobiliário no século XX}

Já avançado o século XX, especificamente depois das intensas erupções do vulcão Irazú, em 1963 e 1965, o excesso de cinzas originadas pelas erupções causaram prejuízos aos produtores de café cujas lavouras se localizavam nas proximidades de San José e eles venderam seus terrenos (Schnell, 2014). É importante acentuar que esse fato representou um dos vetores que impulsionaram o desenvolvimento urbano. A especulação urbana nos terrenos agrícolas também é outra variável a ser levada em conta já que, durante o século XX, muitos donos de fazendas cafeeiras fundaram empresas urbanizadoras e imobiliárias, as quais impulsionaram uma expansão urbana horizontal, e se beneficiaram desse câmbio de renda do solo agrícola para o urbano.

0 processo de urbanização no Valle Central durante a segunda metade do século XX modificou-se em relação aos velhos padrões de urbanização herdados do período colonial. A urbanização e, posteriormente, o processo de metropolização no Valle Central estiveram condicionados pela base econômica e social legada pela colônia. Os fatores que contribuíram para o desenvolvimento do mercado imobiliário no século XX em San José se resumem na Figura 5.

De acordo com Schnell (2014), esse fenômeno de divisão de propriedades responde à demanda por moradia e, em menor medida, à da indústria e do comércio. 0 início das transformações massivas de terrenos agrícolas para usos urbanos aconteceu previamente ao incipiente processo de industrialização na década de 1950. Essa época coincidiu com uma queda nos preços internacionais do café e com a implantação, por parte do Estado, de novas áreas residenciais ao sul do Valle Central. Assim, o consumo principal das novas áreas urbanizadas foi de função residencial e não relacionado à indústria, ao contrário do que aconteceu em outros países da América Latina, como no Brasil. A Figura 6 ilustra uma típica paisagem cafeeira e que posteriormente passa pelo processo de loteamento para dar início ao processo de urbanização nas ladeiras do Valle Central.

Schnell (2014) analisa o estudo de Jiménez (1980), da segunda metade do século XX, no qual ele apresenta transações ${ }^{13}$ imobiliárias no Cantón ${ }^{14}$ Central San José, no período 1950-1974. Mostram-se os loteamentos

\footnotetext{
${ }^{13}$ Segundo Jiménez (1980, p. 5), se entende por transações: “[...] aquelas compras e vendas de terras que surgem de grandes chácaras e que levam a uma divisão em lotes menores" (Tradução nossa).

${ }^{14}$ A Costa Rica está dividida em 7 províncias, com seus respectivos cantones e distritos. A Província de San José tem 20 cantones e 123 distritos.
} 


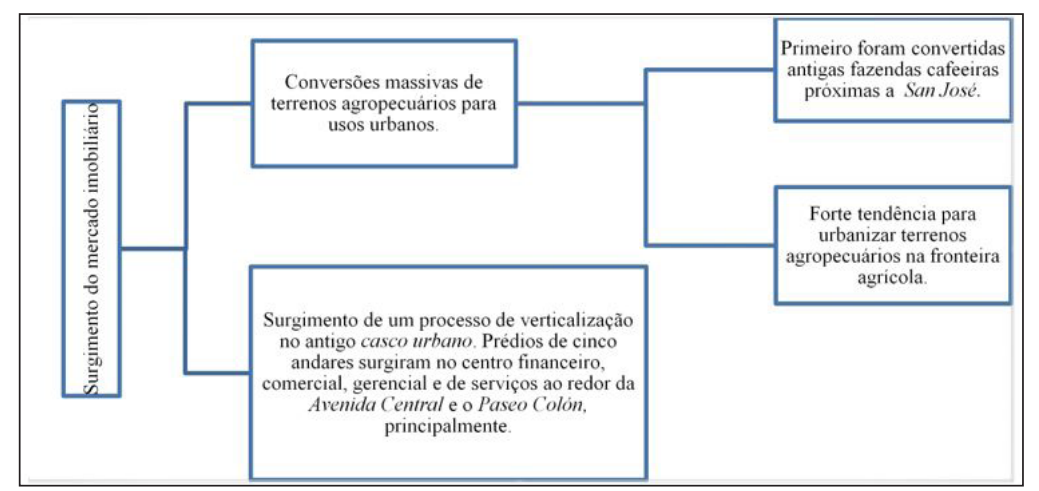

Figura 5 - Fatores que contribuíram para o surgimento do mercado imobiliário em San José Fonte: Autor (2014).

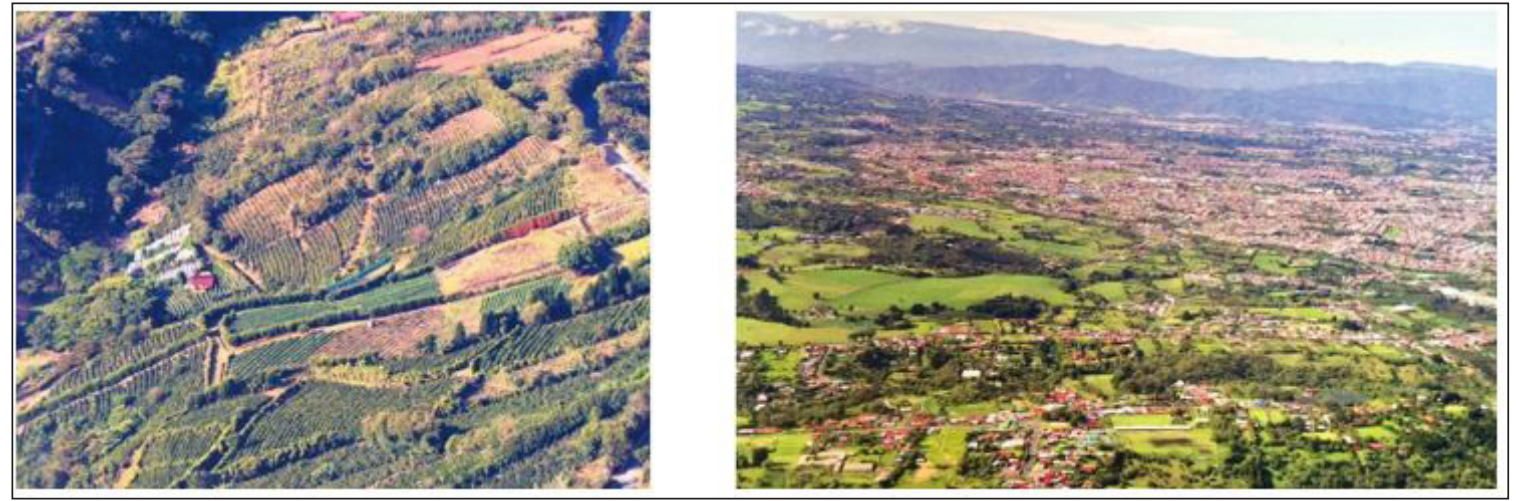

Figura 6 - Paisagens cafeeiras no Valle Central Fonte: Icafé (2014).

de propriedades com superfície aproximada de um hectare ou mais, para se entender as modificações espaciais e como a maioria das propriedades teve sua origem a partir da divisão das terras. A Figura 7 ilustra o aumento das transações imobiliárias que contribuíram para o loteamento das fazendas cafeeiras. Segundo Jiménez (1980), registraram-se 2.186 transações com divisão de 72 das 161 fazendas analisadas entre 1950 e 1974.

Conclui-se que a partir da década de 1960 não se forja mais a grande propriedade e que os poucos proprietários começam uma comercialização progressiva de terras, intensificando a fragmentação e fomentando o padrão horizontal. Jiménez (1980) indica que houve uma compulsiva necessidade de apropriação individual do espaço urbano, o que se reflete no incremento do número de proprietários de residências. Um efeito negativo dessa evolução espacial é que, de forma paulatina, se impôs uma maior apropriação individual do solo e se fomentou

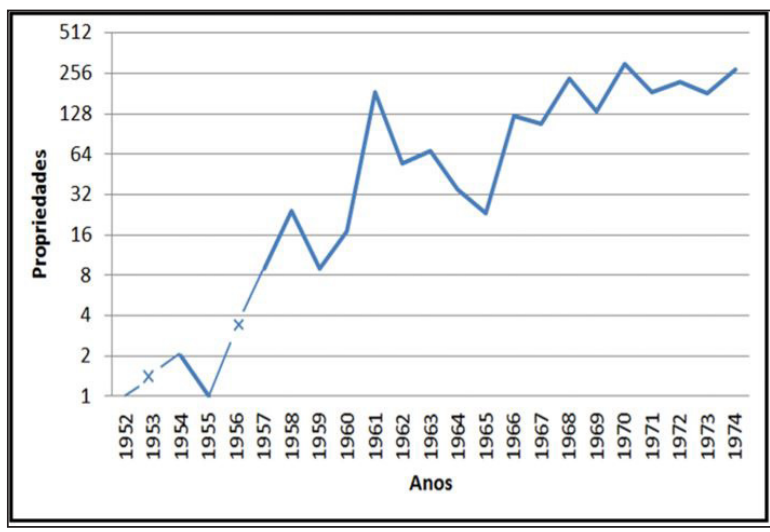

Figura 7 - Total anual de transaç̃oes imobiliárias registradas em San José, 1952-1974

Fonte: Jiménez (1980, p. 90).

a expansão urbana horizontal pelo Valle Central. Isso significa que a verticalização residencial não ocupava um lugar importante nos padrões de moradia no século XX e nem constituía uma primeira opção 
residencial para os costarriquenhos. 0 complemento da pesquisa de campo comprovou que o padrão horizontal prevaleceu, mantendo os padrões de casas e propriedades espaçosas com acesso a jardins ou espaços abertos de lazer.

\section{A protoverticalização em San José: a criação de uma cidade moderna}

No século XX, no contexto do período Republicano, surgem vários projetos do Estado para construir altos edifícios institucionais, como símbolo de progresso. Com a introdução de novas tecnologias da construção civil e a utilização do concreto armado, a paisagem de San José começa a evidenciar um incipiente processo de verticalização, no entanto principalmente no setor institucional. Esse pode ser considerado como o começo da verticalização na Costa Rica, ou protoverticalização, já que o prefixo proto se refere ao primeiro momento do processo como tal, que um século depois começa com força no setor residencial (Schnell, 2014).

Essa verticalização inicial começa a ter impactos nas técnicas de produção do espaço e nos desdobramentos na estrutura interna da cidade. Também a produção em forma vertical de prédios públicos vai paralela à construção dos valores de desenvolvimento que legitimam a conformação de um consenso simbólico (Schnell, 2014). Esses primeiros projetos contribuíram para a criação da cidade moderna e desenvolvida dentro de um contexto no qual o país estava crescendo econômica, política e socialmente. A verticalização se localizava onde o poder na cidade estava, no entanto não incluía o setor residencial, como ocorreu em outros países da América Latina nesse momento (Schnell, 2014).

Em relação ao setor residencial, algumas casas da elite costarriquenha, desde inícios do século XX, começavam a apresentar estruturas com térreo e um ou dois andares (Figura 8), no entanto sempre mantinham acesso a um jardim ou área verde na propriedade.

Esses primeiros bairros, com casas de luxo de dois ou mais andares, começaram a marcar diferenças na morfologia urbana desde o período Republicano, no entanto, num país sismicamente ativo, o costarriquenho nunca optou pela tendência de verticalização residencial intensiva.

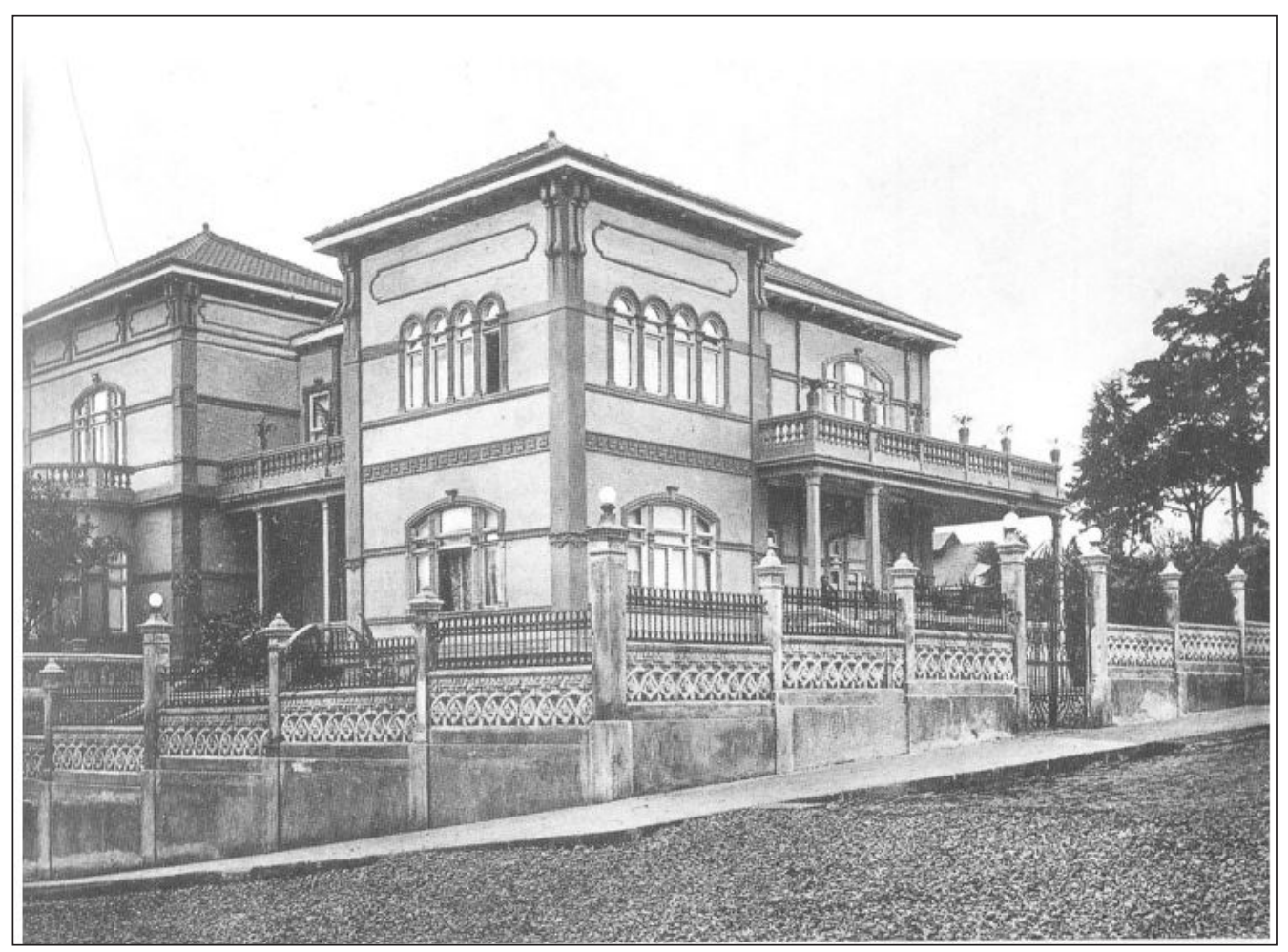

Figura 8 - Exemplo de moradia de dois ou mais andares da elite costarriquenha no século XX: residência Dr. A. Perry, San José; atualmente abriga a Asamblea Legislativa Fonte: Gómez \& Zamora (2008, p. 151). 


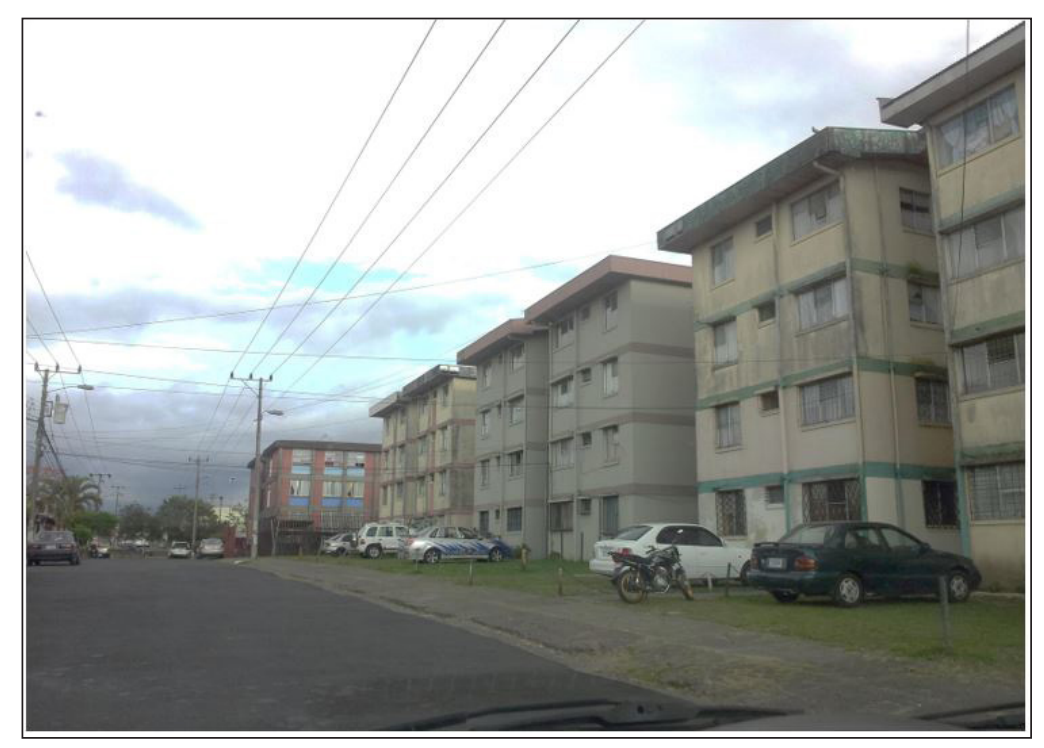

Figura 9 - Exemplos de multifamiliares voltados para os segmentos baixos em Hatillo 6

Fonte: Acervo do autor (2014).

Cabe ressaltar que essa realidade de alta sismicidade atua como fator condicionante nesse tipo de desenvolvimento e condiciona também a definição de verticalização no país. Mesmo que em outros países o número de pavimentos não seja um dos indicadores mais importantes para qualificar a verticalização, no caso costarriquenho a sismicidade assume alta importância e é condicionante para as construções civis. Prédios de três ou quatro pavimentos já podiam ser considerados parte do processo de verticalização, já que os avanços tecnológicos eram imprescindíveis para se poder construir esse tipo de estruturas. Embora a partir dos anos 1970 tenha sido publicado o Código Sísmico ${ }^{15}$ e regulada a qualidade e segurança das construções, a pesquisa de campo corroborou que o aceite e a confiança na verticalização evoluíram lentamente, o que poderia sugerir que os condicionantes geomorfológicos não constituem o fator principal da resistência à verticalização residencial.

Os primeiros casos de moradias em formato vertical corresponderam aos projetos de bem-estar social.

\footnotetext{
${ }^{15}$ Os Códigos Sísmicos coletam, sintetizam e organizam conjuntos de regras e práticas para realizar desenhos sismo-resistentes, produto do conhecimento científico, tecnológico, a prática e a experiência dos últimos terremotos. Na Costa Rica, o primeiro Código Sísmico foi publicado em 1974 (CSCR-74). As seguintes versões foram em 1986, 2002 e 2010. Antes de1974 se utilizava como referência o Blue Book da Structural Engineers Association of California (SEAOC) (Schnell, 2014).
}

Esse é outro motivo da existência de preconceito associado aos prédios residenciais, especificamente com relação aos chamados multifamiliares, já que são associados a projetos realizados pelo Instituto Nacional de Vivienda y Urbanismo para os segmentos socialmente semi-inferiores, nos anos 1950, como parte da Lei Casas Baratas, de 1942. Na década seguinte construíram-se os Multifamiliares Calderón Muñoz, inspirados na Unité d'habitation, de Le Corbusier, em Marselha. Também se construiu a cidade satélite Hatillo, em 1955, inspirada nas cidades-jardim da Inglaterra. A Figura 9 mostra o tipo de arquitetura desses prédios destinados aos segmentos de menor poder aquisitivo.

A percepção desses multifamiliares se degrada pela ideia de que são para "pobres", com quartos e áreas comuns muito pequenas, sem privacidade e sem isolamento acústico (Schütte, 2010). Os espaços abertos e os amplos jardins estavam destinados aos segmentos de maior poder aquisitivo. Essas características negativas associadas à habitação coletiva vêm sendo lentamente mudadas ao longo do tempo: atualmente estão sendo vendidas como símbolos de luxo.

Posteriormente, existiram tentativas de construir prédios residenciais não associados aos segmentos mais baixos. Em 1962 foi construído o Edificio Solera, em San José (Figura 10), e em 1965, o edifício de apartamentos San Marcos, em Barrio Dent, moradias verticais para o segmento de alta renda. 


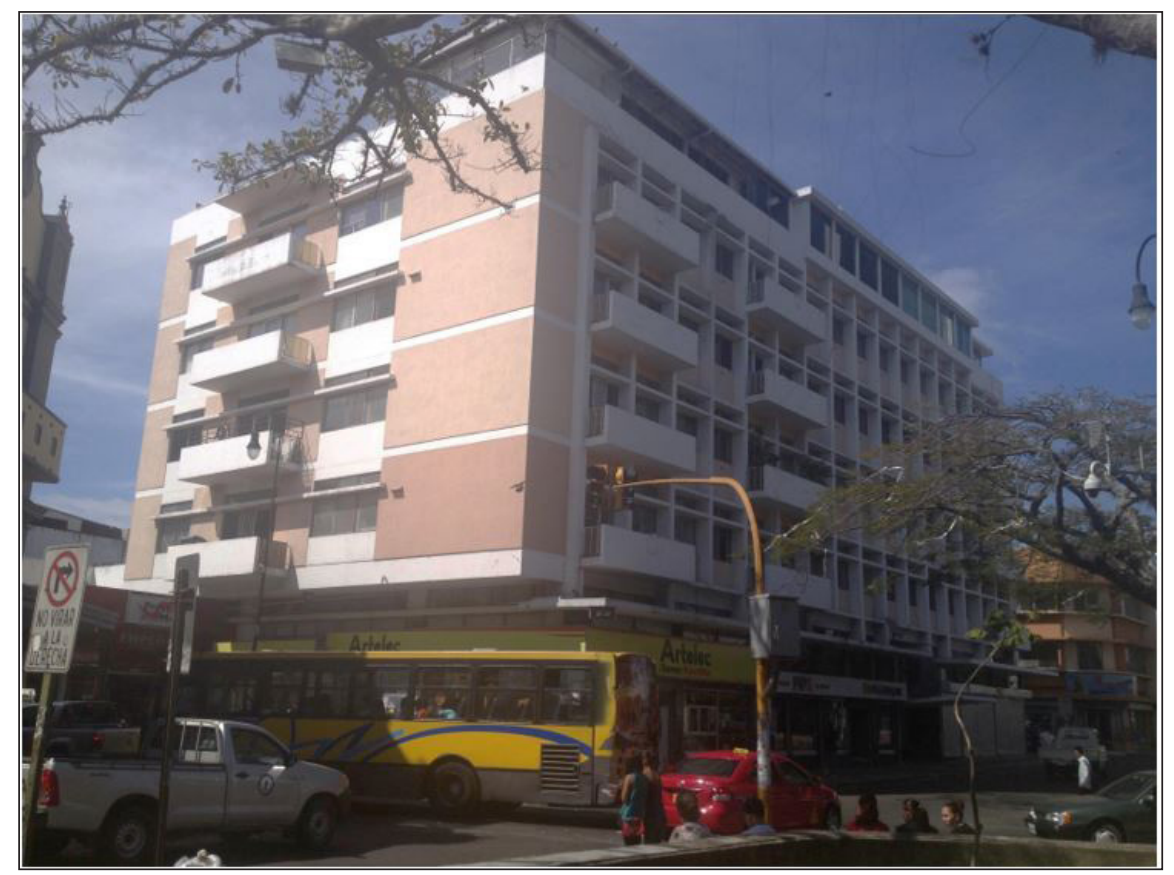

Figura 10 - Edificio Solera Benett, 1962: primeiras residências verticais voltadas para classe alta na Costa Rica, no século XX Fonte: Acervo do autor (2014).

Essas foram as primeiras propostas de residência nas quais os proprietários eram donos de propriedade que era parte de um edifício sem espaços abertos ou jardins. A tendência residencial não teve muito êxito entre os costarriquenhos e poucos projetos foram construídos de forma verticalizada no século XX (Figuras 10 e 11) (Schnell, 2014). Isso indicaria que embora ao longo do tempo se tenha alterado o universo semântico associado à moradia vertical e embora as tecnologias construtivas tenham vencido os desafios geomorfológicos, a resistência dos costarriquenhos continuava sendo, principalmente, o arraigo à terra ou aos espaços abertos, como jardins.

\section{A atual tendência de verticalização e seu lento aceite}

Entrando no século XXI, começaram a aparecer os primeiros prédios verticais perto do centro da capital, mas voltados para os altos segmentos (Figura 12). Essa tendência introduziu novos desafios para o forte arraigo pelo espaço livre. Um auge inesperado e intenso tem-se evidenciado na oferta de um novo conceito de moradia pouco vivenciado pelos costarriquenhos (Schnell, 2014, 2016).

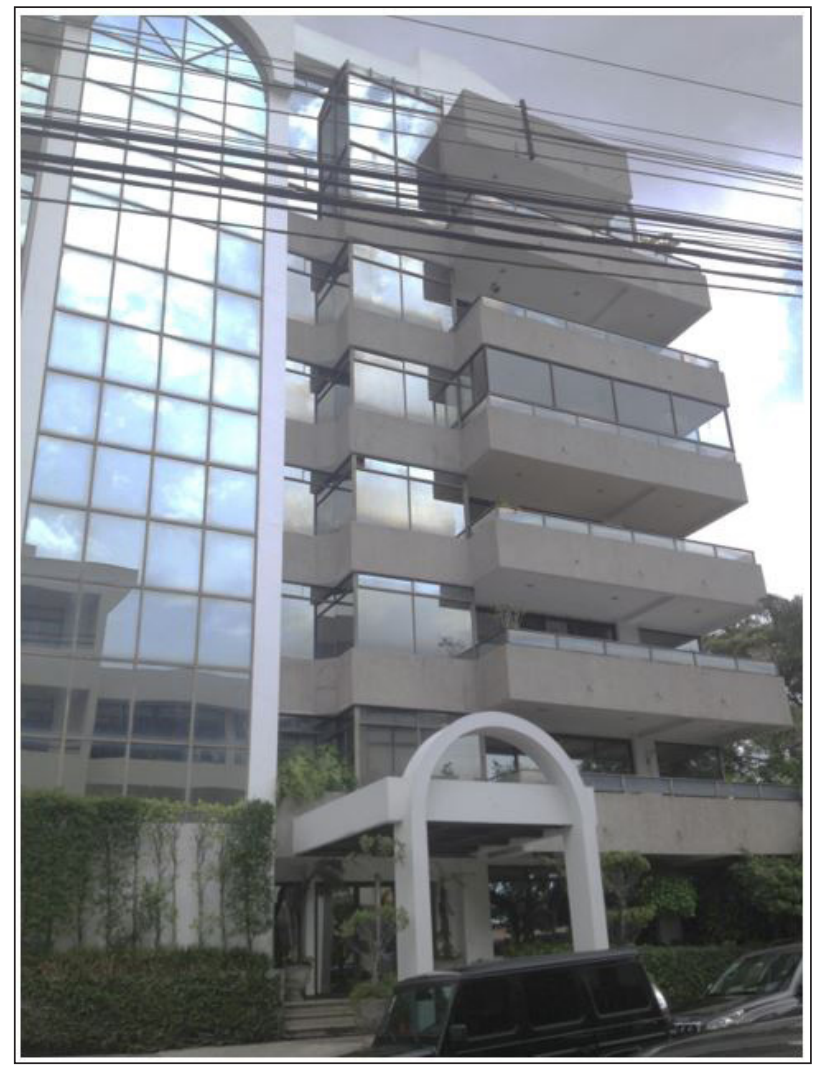

Figura 11 - Exemplo dos escassos projetos residenciais verticais do século XX, no bairro Rohrmoser

Fonte: Acervo do autor (2013). 


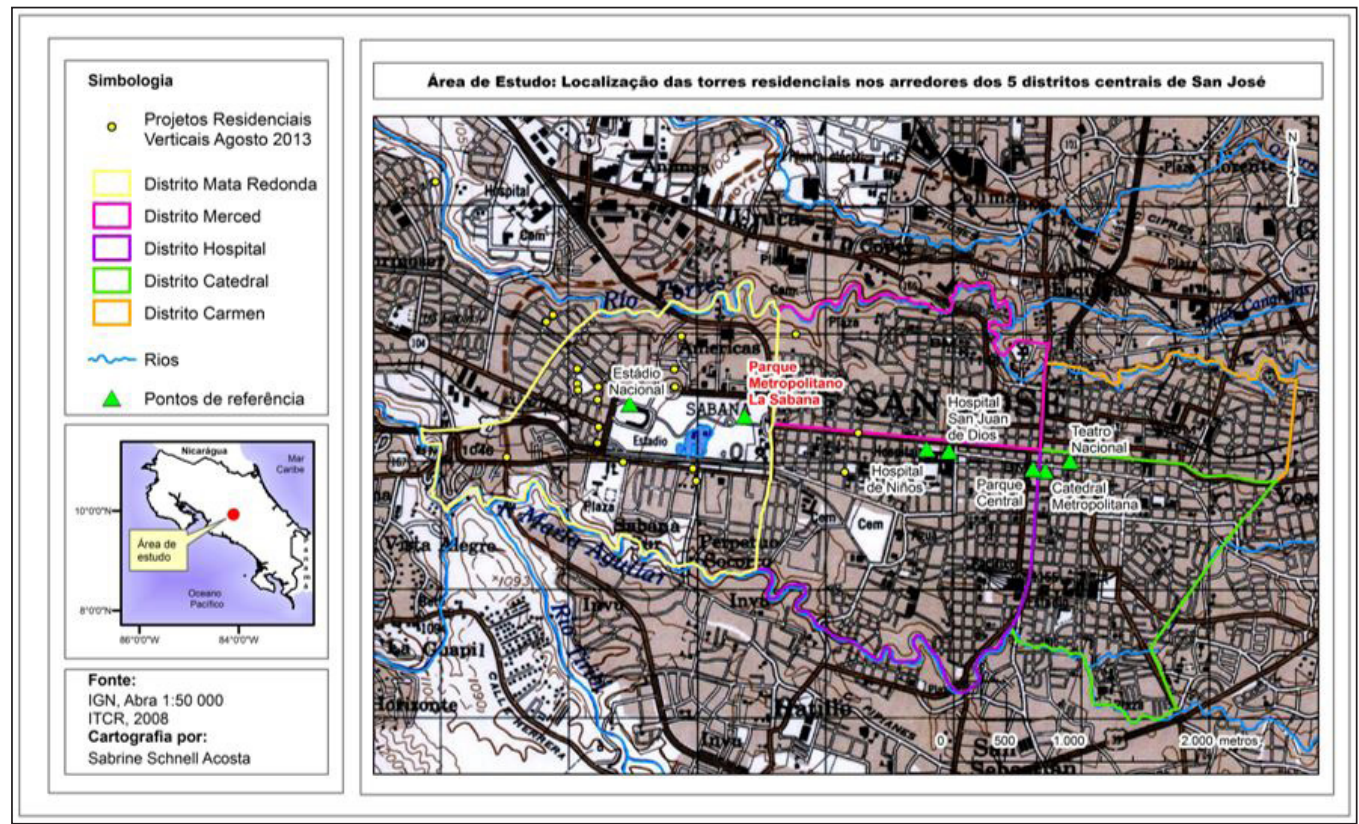

Figura 12 - Área de estudo: localização das torres nos cinco distritos centrais da capital San José Fonte: Acervo do autor (2014).

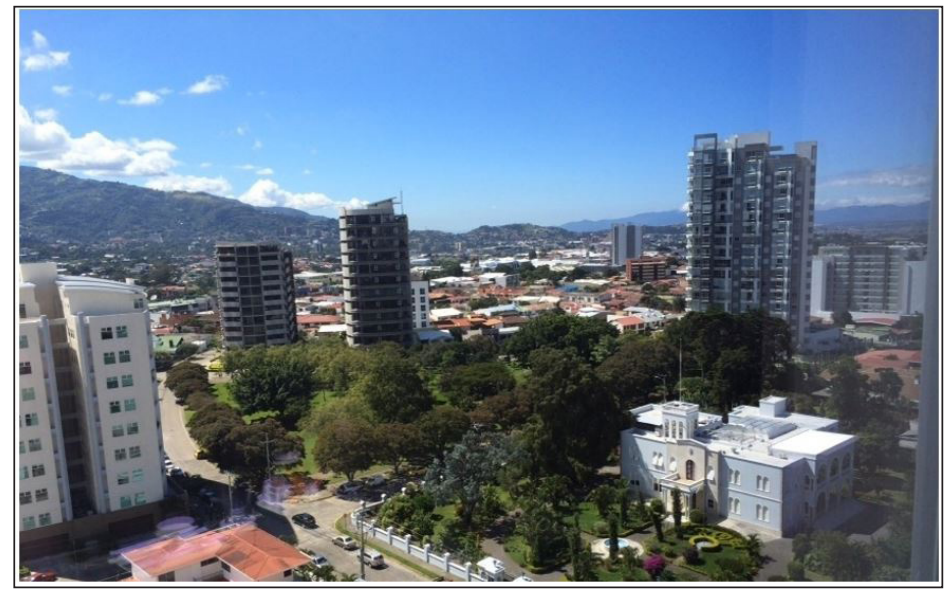

Figura 13 - Oeste de San José (distrito Mata Redonda)

Fonte: Acervo do autor (2016).

O jornal Actualidades Inmobiliarias (2016) registrou 87 edificações de três ou mais andares na Gran Área Metropolitana, em 2016, e a revista Inversión Inmobiliaria (Retana \& Piñar, 2016) indica que os setores que enfatizam a produção vertical são o oeste de San José, com 4.532 unidades, e o leste de San José, com 2.736 unidades. No entanto, especificamente para a área circundante dos cinco distritos centrais da capital, Schnell (2014) reportou 20 torres de luxo em 2013 (Figuras 12 e 13).
Atualmente, San José, como província, tem aproximadamente 1.621.393 habitantes ${ }^{16}$ (INEC, 2017). 0 registro fotográfico atual e a análise semântica da publicidade permitem observar que novos investimentos e atrativas tendências internacionais para a construção de altos prédios de luxo têm atraído o olhar dos costarriquenhos como novo símbolo de progresso e

\footnotetext{
${ }^{16}$ A província San José, com uma área de $4965,9 \mathrm{~km}^{2}$ está dividida em 20 cantones. 0 Cantón Central ou Cantón San José tem uma área de $45 \mathrm{~km}^{2}$ e 339581 habitantes (INEC, 2017).
} 
status e não necessariamente para aumentar a oferta de unidades residenciais para a crescente população. Diversas casas de alto padrão têm sido demolidas para abrir espaços para os novos prédios (Figura 14).

Nos últimos 10 anos, a população começou a sacrificar o arraigo pela terra que se manteve vigente até o século XXI. Podemos considerar que as torres residenciais com seus luxuosos lobbys e imponentes alturas estão longe de ser associadas a uma forma residencial dos menos favorecidos e atualmente formam parte das paisagens dos segmentos de maior poder aquisitivo (Schnell, 2014, 2016).

Todo esse processo de verticalização tem introduzido tipologias habitacionais novas, novos espaços de expansão urbana que estão sendo incorporados ao tecido urbano metropolitano. São novos espaços produtivos associados a tecnologias mais elaboradas e a formas de crescimento nas quais diferentes articulações entre Estado e capital imobiliário interagem (Mendonça \& Costa, 2011). 0 forte arraigo pela terra está sendo sacrificado num contexto de urbanização neoliberal que comanda as novas propostas e preferências dos costarriquenhos.

Essa verticalização da moradia de lento aceite em San José representa não somente uma transformação da paisagem (Figura 15), mas também de significados e valores associados ao espaço urbano e às relações interpessoais.

Por exemplo, ao se afastar da rua, o apartamento faz com que o contato físico entre a rua e os pedestres se perca; aquele contato que foi muito importante desde o período colonial e caracterizou os primeiros assentamentos no Valle Central (Schnell, 2014). Nos espaços circundantes dos quatro distritos centrais de San José não se fomenta um relacionamento na rua. Ainda está presente a ideia de que o centro é um lugar perigoso e que cada pessoa pode morar e sentir-se segura em seu apartamento sem necessidade de interagir com a rua.

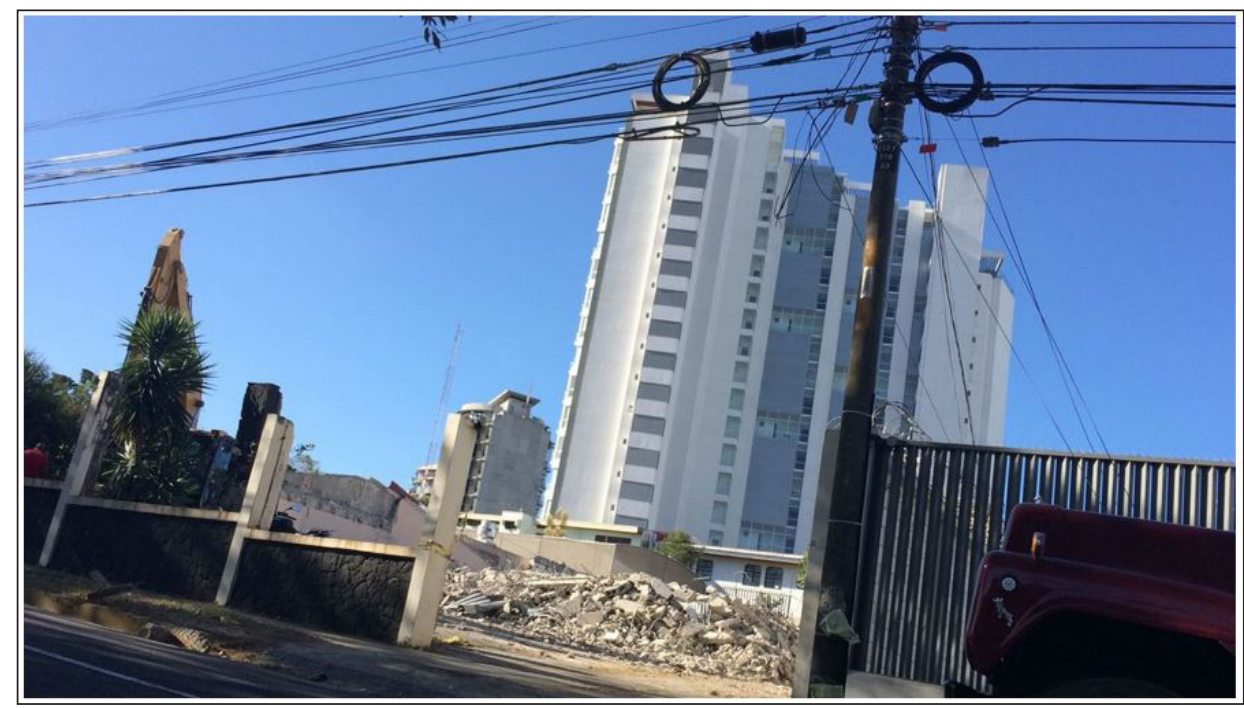

Figura 14 - Casa demolida parar abrir espaço para futuros projetos residenciais verticais no bairro de alto padrão Rohrmoser Fonte: Acervo do autor (2016).

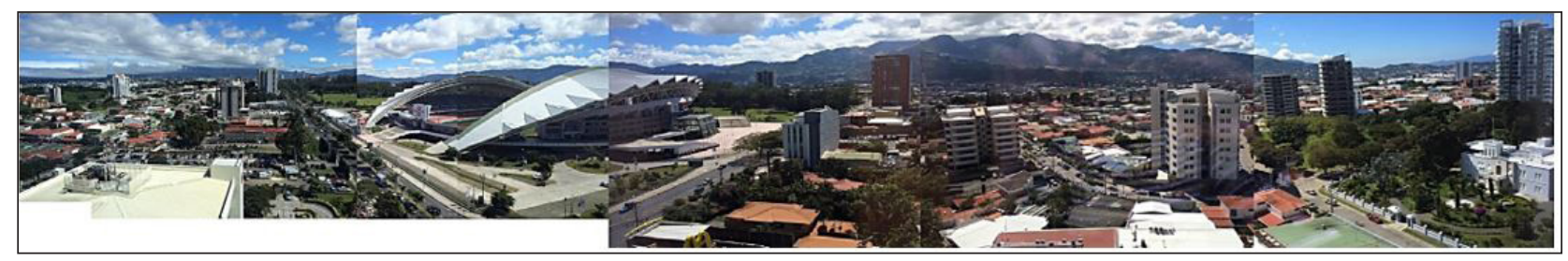

Figura 15 - Visão 180 graus da verticalização residencial a oeste do Parque Metropolitano La Sabana, no bairro Rohrmoser Fonte: Acervo do autor (2016). 
A moradia verticalizada se encerra em um plano único e as excepcionais relações que se estabelecem com o meio externo são através das janelas. Não existe mais, como na habitação indígena ou pós-colonial, um significado da casa profundamente enraizada na natureza que está ao redor. Como se observou no início da análise, o contato com o mundo exterior, a chácara, era uma característica essencial do costarriquenho que sobreviveu a uma transição para o capitalismo e conseguiu manter a relação simbiótica entre seu modo de produção e o capitalista (Schnell, 2013). Eis a importância da relação entre a natureza, o jardim e o espaço aberto e a cultura costarriquenha de moradia (Acosta, 2017). A propriedade verticalizada vem mudar esses padrões que existiram durante séculos. Para tentar mascarar essa falta de contato com a natureza, as táticas de publicidade têm tentado fazer alusão ao componente "natureza" em diálogo com a característica "urbana" (Figura 16) (Acosta, 2017).

Embora os textos e as imagens aludam à vegetação, aos espaços abertos, à tranquilidade, ao luxo, à natureza e, ao mesmo tempo, à cidade contemporânea (Acosta, 2017), esse novo conceito de moradia coloca em xeque as novas decisões dos costarriquenhos na aceitação dessa nova forma de moradia sem acesso direto a um espaço natural de sua propriedade.

A natureza como mercadoria se torna um bem de consumo associado ao luxo (Acosta, 2017).
A possibilidade de morar num empreendimento de alto padrão no centro da cidade e em contato com alguma forma de natureza ou com elementos que aludam ao arraigo pela terra é um privilegio de alto preço evidenciado pela publicidade. Na última década, em San José, o apartamento passa a ser associado ao luxo e à segurança, como símbolo elitizado do bom gosto (Figura 17) (Acosta, 2017; Schnell, 2016). Inclusive o medo de morar em edificações verticais devido à prevalência geomorfológica deixou de ser um condicionante tão forte e as inovações tecnológicas têm contribuído para elidir o temor e resistência de morar em vertical.

A localização das torres no traçado urbano também implica status. 0 centro está começando a representar um espaço social dominado pelas elites, como uma vez aconteceu nos inícios da cidade. As incipientes torres podem ser observadas na imagem aérea do bairro Rohrmoser (antigamente terras cafeeiras) (Figura 18).

Atualmente, morar perto do centro simboliza a inserção do indivíduo e sua família dentro dos altos segmentos da sociedade, tentando deixar de lado a visão de centro urbano associado a um lugar decadente e perigoso, sem natureza (Schnell, 2014). As novas relações que se constroem, tanto as interpessoais como aquelas entre o indivíduo ou grupos e o espaço, resultam em novas configurações do espaço físico,

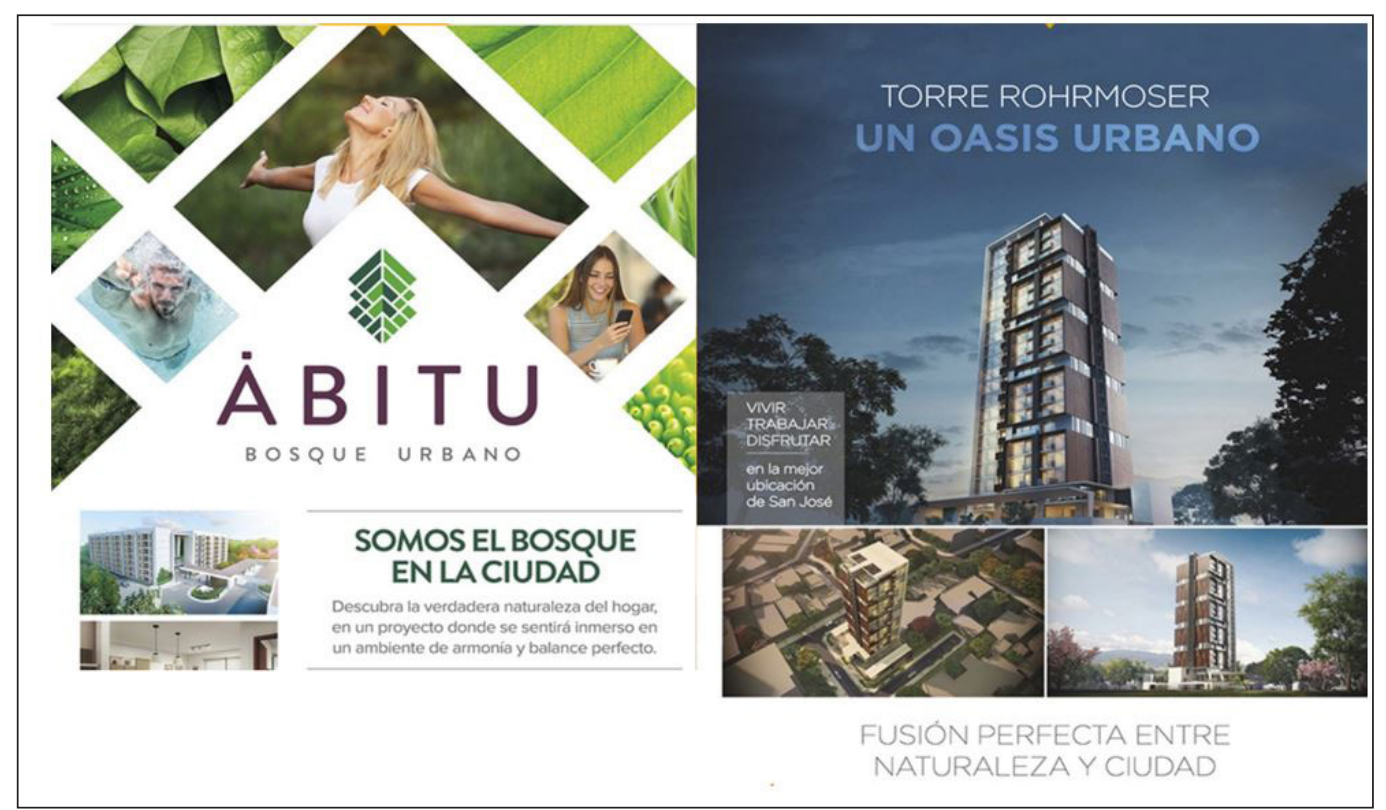

Figura 16 - Publicidade dos recentes empreendimentos verticais tentando fazer alusão ao componente natureza perto da cidade Fonte: Revista CR Property Hunters (2015). 


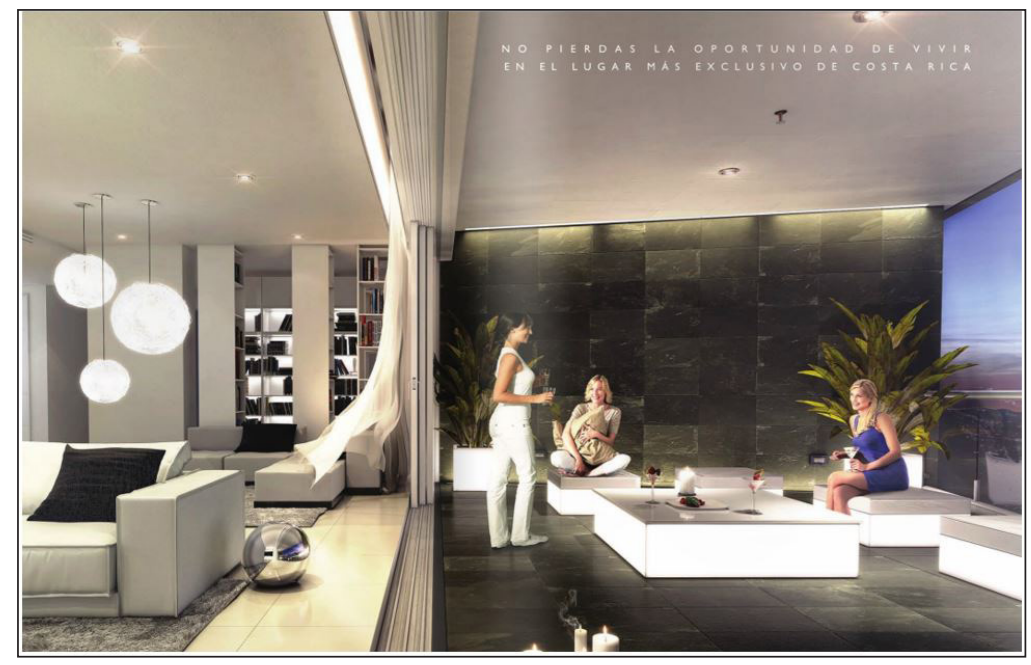

Figura 17 - Publicidade fazendo alusão aos novos empreendimentos verticais vendendo a ideia de luxo Fonte: Revista 4 Sale by Owner (2013).

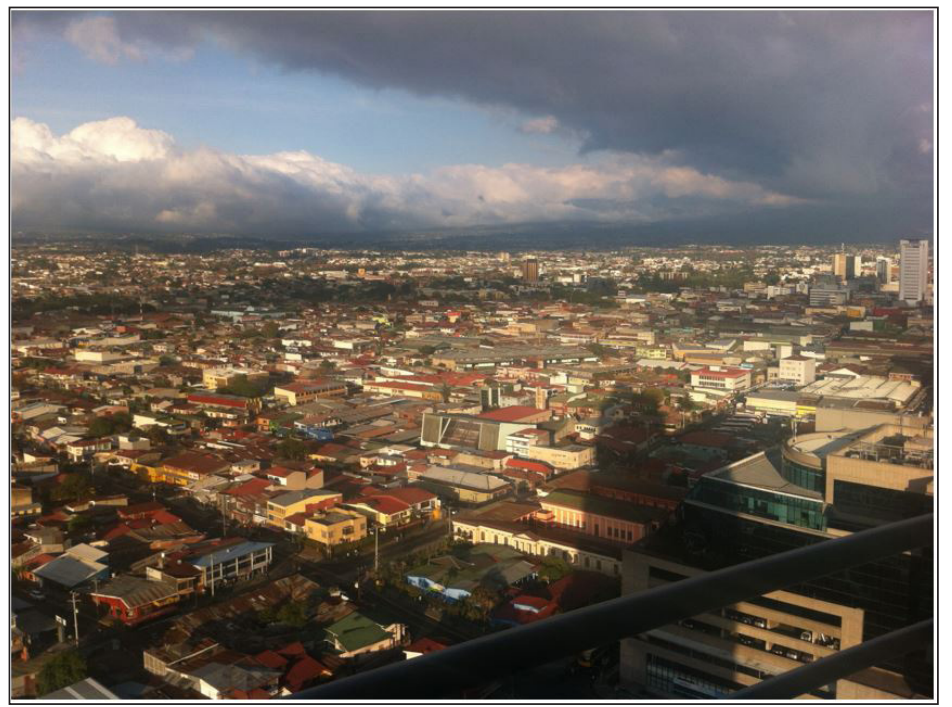

Figura 18 - Vista aérea desde o prédio de luxo Torres Paseo Colón, no centro de San José Fonte: Acervo do autor (2013).

que se transforma buscando adaptar-se a novas demandas, no entanto sempre prevalecendo o forte arraigo pela terra.

\section{Considerações finais}

No século XV, as tendências de moradia da população que habitou o território atualmente conhecido como Costa Rica apresentaram um forte arraigo pela terra, à terra de cultivo, de sobrevivência, fonte de alimentos e, por que não, de lazer. Conforme a colônia espanhola se inseriu no mercado mundial capitalista, as mudanças no modo de produção não implicaram um desarraigo do camponês por sua terra de cultivo, como ocorreu com outros países da América Latina e da mesma América Central. Ao manter o vínculo com o jardim ou espaço de cultivo, essa relação simbiótica permitiu manter os padrões de relações sociais entre vizinhos, famílias, o entorno e os cultivos. Observou-se como o surgimento do mercado imobiliário foi paralelo às mudanças e intensidade do uso do solo. A divisão das 
terras como resposta ao crescimento populacional começou a ameaçar o tamanho das propriedades de herança, a disponibilidade de acesso a jardim próprio e, inclusive, a terreno apropriado ao cultivo de sobrevivência ou para comércio de produtos. O complemento de pesquisa de campo e a análise de fotografias constataram que o padrão de expansão horizontal afiançou e fortaleceu o forte arraigo pela terra e o acesso aos jardins e espaços abertos.

No final do século XIX e na primeira metade do século XX surgiu o que poderíamos propor de protoverticalização. Com o objetivo de fazer da cidade um símbolo de progresso, o costarriquenho começou a adotar uma nova tendência de construir em vertical. Inicialmente, as primeiras tentativas foram associadas a suntuosas casas de alto padrão e, com os avanços na construção civil, o concreto armado predominou nos edifícios do Estado. Apesar do surgimento de novas tecnologias antissísmicas, conforme o tempo passou, o costarriquenho continuou não aceitando o formato residencial vertical. Alguns projetos em torres associaram-se a projetos de bem-estar social na metade do século XX. Na década de 1970, o Código Sísmico estabeleceu regras e práticas para realizar desenhos sismo-resistentes, no entanto o forte arraigo pela terra perdurou como fator forte para manter a resistência ao padrão vertical.

O trabalho de campo e a análise semântica confirmaram como, atualmente, no século XXI, a tendência de moradia vertical tomou força e está sendo associada com o luxo. Essa característica tem um preço alto a ser pago, e que nem toda a população está disposta a pagar: a falta de contato com um jardim ou terreno para cultivo ou lazer e a falta de contato com espaço verde próprio. A revisão das novas táticas de publicidade evidenciou como essas fazem alusão ao conceito da natureza para tentar convencer os costarriquenhos a adotar essa nova forma de moradia muito distante de seu imaginário e de seu legado colonial.

Embora outras pesquisas, desde outras perspectivas, possam propor outras explicações para o lento aceite da verticalização, essa revisão bibliográfica se focou no forte arraigo pela terra como principal fator. $\mathrm{O}$ amplo recorte temporal, desde o período colonial, permitiu desvendar como as crescentes divisões dos terrenos agrícolas para abastecer a demanda de moradia e, posteriormente, do crescimento horizontal urbano tentaram manter o forte arraigo pela terra, até o século
XX. A pesquisa em campo confirmou que, atualmente, no século XXI, no contexto da urbanização neoliberal e com as táticas de publicidade imobiliária, se está tentado convencer uma população que durante séculos manteve um forte arraigo pela sua terra e se defendeu dos câmbios nos modos de produção. Agora essas novas tendências de verticalização residencial sacrificam as relações com o mundo exterior e as janelas são a única forma de olhar para uma cidade que uma vez começou formada por chácaras e casas isoladas que desfrutavam de amplas extensões de terra, com seus cultivos de sobrevivência.

\section{Referências}

Acosta, S. (2017). Estrategias de venta del mercado inmobiliario costarricense: la naturaleza como mercadería. Revista Ciência e Trópicos, 41(1), 55-75.

Actualidades Inmobiliarias. (2016, março). 5(48), 12-13.

Baires, Y. (1975). Las transacciones inmobiliarias en el Valle Central y la expansión cafetalera de Costa Rica (1800-1850) (Tesis de licenciatura). Universidad de Costa Rica, Ciudad Universitaria Rodrigo Facio Brenes.

Bustamante, T. (1996). La ciudad de San José: ensayo histórico. San José: Municipalidad de San José.

Gómez, M., \& Zamora, F. (2008). Costa Rica en fotografías antiguas: recopilación libros I y II. San José: Jadine.

González, C. (1973). San José y sus comienzos. Revista de Costa Rica, (3), 111-137.

Hall, C. (1976). El café y el desarrollo histórico-geográfico de Costa Rica (2. ed.). San José: Editorial Costa Rica.

Icafé. (2014). Café de Costa Rica: el espíritu de una nación. San José: Ojalá Ediciones.

Instituto Geográfico Nacional - IGN. (1989). Hoja Topográfica Abra 1: 50000 (3. ed.). Madrid: IGN.

Instituto Nacional de Estadística y Censo - INEC. (2017). Recuperado em 24 outubro de 2017, de http://www.inec. go.cr/poblacion

Investigación del Instituto Tecnológico de Costa Rica - ITCR. (2008). Atlas de Costa Rica. Costa Rica: ITCR.

Jaramillo, S. (2009). Hacia una teoría de la renta del suelo urbano (2. ed.). Bogotá: Universidad de los Andes, Facultad de Economía, CEDE, Ediciones Uniandes. 
Jiménez, E. (1980). Proceso de urbanización y transacciones inmobiliarias en el Cantón Central de San José 19501974 (Licenciatura). Universidad de Costa Rica, Ciudad Universitaria Rodrigo Facio Brenes.

Lefebvre, H. (1995). The production of space (404 p.). Cambridge: Blackwell. The world market creates configurations and inscribes changing spaces on the surface of the earth, spaces governed by conflicts and contradictions (tradução nossa).

Lefebvre, H. (2006). O direito à cidade (4. ed.). São Paulo: Centauro.

Lukács, G. (1981). 0 marxismo ortodoxo. In G. Lukács, Sociologia. São Paulo: Ática.

Marx, K. (1983). 0 método da economia política. In K. Marx, Contribuição à crítica da economia política (2. ed., pp. 218-219, Trad. M. H. Alves). São Paulo: Martins Fontes.

Marx, K. (1988). O Capital. Rio de Janeiro: Bertrand Brasil.

Mendonça, J. G., \& Costa, H. S. M. (2011). Dinâmica imobiliária e a formação de um "obscuro objeto de desejo": localização residencial e representação simbólica. In J. G. Mendonça, \& H. S. M. Costa (Eds.), Estado e capital imobiliário: convergências atuais na produção do espaço urbano brasileiro. Belo Horizonte: C/Arte.

Molina, I. (1991). Costa Rica (1800-1850): el legado colonial y la génesis del capitalismo. San José: Editorial de la Universidad de Costa Rica.

Núñez, F. M. (1973). Panorama de la Villita de la Boca del Monte. Revista de Costa Rica, (4), 25-35.

Quesada, F. (2011). La modernización entre cafetales, San José, Costa Rica, 1880-1930. Ciudad Universitaria Rodrigo Facio: Editorial UCR.

Retana, K. \& Piñar, A. (2016). ¿Saturación en vivienda? Depende de quién. Revista Inversión Inmobiliaria, (7), 52-58.

Revista 4 Sale by Owner. (2013). 1(110), 19.

Revista CR Property Hunters. (2015). (29), 37-39.
Saad, A., Fo. (2011). A dialética materialista. In A. Saad, Fo. O valor de Marx (pp. 19-41). Campinas: Editora da Unicamp.

Santos, M. (2012). Metamorfose do espaço habitado (6. ed., 1. reimp.). São Paulo: Edusp.

Schnell, S. (2013). A transição para o capitalismo na Costa Rica: uma colônia hispânica seduzida pelo grão de ouro. Revista Formação, 1(20), 78-93.

Schnell, S. (2014). Expansão urbana em San José, Costa Rica: da formação da metrópole à verticalização (Dissertação de mestrado). Universidade Federal de Santa Catarina, Florianópolis.

Schnell, S. (2016). As recentes tendências no mercado imobiliário costarriquenho. Revista Geo UERJ, (28), 1-25.

Schütte, O. (2010). Sobre urbanismos: cuaderno de GAMISMO: cultura y desarrollo urbano en la gran área metropolitana de Costa Rica (pp. 15-43). San José: FLACSO.

Souza, M. A. (1994). A identidade da metrópole: a verticalização em São Paulo. São Paulo: Huitec.

Sposito, M. E. B. (2002). Capitalismo e urbanização. São Paulo. Editora Contexto.

Vega, J. L. (1981a). Aspectos de la diferenciación socialurbana del siglo XIX en Costa Rica. San José: Instituto de Investigaciones Sociales, Facultad de Ciencias Sociales, Universidad de Costa Rica. Proyecto "Poblamiento y Ocupación territorial en Centro América 1870-1940”.

Vega, J. L. (1981b). San José en la transformación social del espacio regional: siglo XIX. Anuario de Estudios Centroamericanos, (7), 85-109.

Vega, J. L. (1988). San José: tenencia de la tierra y nuevos grupos sociales en el siglo XIX. In R. Fernández, \& M. Lungo (Eds.), La estructuración de las ciudades capitales centroamericanas (pp. 161-181). San José: EDUCA.

Recebido: Maio 28, 2017

Aprovado: Jan. 01, 2018 